\title{
Thromboembolic Prophylaxis in Hospitalized Patients with Risk Factors: An underemphasized issue?
}

\author{
Hastanede Yatan ve Venöz Tromboemboli Riski Taşıyan Hastalarda \\ Tromboemboli Profilaksisi: Gereken önem veriliyor mu?
}

\author{
Nesrin Kıral, Sevda Şener Cömert, Coşkun Doğan, Demet Turan, Gülşen Saraç, Benan Çağlayan \\ Dr. Lütfi Kırdar Kartal Training and Research Hospital, Department of Pulmonary Diseases, Istanbul, Turkey
}

\begin{abstract}
Objective: Pulmonary embolism (PE) is frequent among hospitalized patients, with a high morbidity and mortality rate. Although prophylaxis for PE and deep venous thrombosis (DVT) is accepted worldwide and the procedures are routinely applied, prophylaxis may sometimes be ignored in risk groups. The aim of our study was to evaluate the rates of DVT prophylaxis in risk groups among patients hospitalized in our hospital.
\end{abstract}

Materials and Methods: This cross-sectional study was conducted in January 2008 at Dr. Lutfi Kirdar Kartal Training and Research Hospital. Patients hospitalized in our surgery, orthopedics, intensive care, internal medicine, oncology, plastic surgery, obstetrics and gynecology, pulmonary diseases, neurology, neurosurgery and urology clinics were visited on the same day to evaluate the patients clinically and their medical records. Risk factors for DVT and PE were determined and patients receiving prophylaxis were documented.

Results: For the 275 patients, 134 (48.7\%) females and 141(51.3\%) males, included in the study, the average length of hospital stay was $8.1 \pm 10.1$ days. The most frequent risk factors were advanced age $(52.0 \%)$, immobility $(38.9 \%)$, history of operation $(36.4 \%)$, malignancy (28.7\%) and obesity (21.1\%). Among 170 patients who should receive prophylaxis, only 56 (32.9\%) were found to receive prophylaxis. The highest rate of prophylaxis was given by the Orthopedics (84.6\%) and the Neurology (60.0\%) clinics, followed by the Intensive Care Unit (37.5\%). During the study period, no patient was found to receive VT prophylaxis in the Gynecology, Oncology, Plastic Surgery and Urology Departments.

Conclusion: We have found out that in our hospital, the importance of DVT prophylaxis was not fully practiced. Prophylaxis of high

\section{ÖZET}

Amaç: Pulmoner emboli (PE), hastanede yatan hastalarda sık görülen, morbidite ve mortalitesi yüksek bir hastalıktır. PE’lerin önemli bir kısmı alt ekstremite derin venöz sisteminden kaynaklanır ve bu derin ven trombozları (DVT) çoğunlukla asemptomatiktir. DVT ve PE proflaksisi tüm dünyada kabul gören, rutin kullanıma girmiş yöntemler olmasına karşılık risk grubundaki hastalara proflaksi uygulamaları ihmal edilebilmektedir. Çalışmamızı, hastanemizde yatan ve risk faktörü taşıyan hastalarda DVT proflaksisinin hangi sıklıkta uygulandığını araşıırmak için planladık.

Gereç ve Yöntem: Hastanemizin cerrahi, ortopedi, yoğun bakım, dahiliye, onkoloji, plastik cerrahi, kadın doğum, gögüs hastalıkları, nöroloji, nöroşirürji ve üroloji kliniklerinde yatan hastalar, aynı gün içinde ziyaret edilerek, hem kendileri hem de dosyaları görüldü. DVT ve PE için risk faktörleri saptandı. Proflaksi alması gerekip gerekmediği, 2001 ACCP kriterlerine göre belirlendi. Proflaksi alıp almadığ1, proflaksiye kontrendike bir durumu olup olmadığ 1 kaydedildi.

Bulgular: Hastanemizde yatan 275 hasta ziyaret edildi ve dosyas incelendi. Hastaların 134'ü $(\% 48,7)$ kadın, 141'i $(\% 51,3)$ erkekti ve yaş ortalamaları 53,09 \pm 19 idi. Hastanede ortalama yatış sürelerinin $8,1 \pm 10,1$ gün olduğu saptandi. En sık saptanan risk faktörleri ileri yaş $(\% 52,0)$, immobilite $(\% 38,9)$, operasyon öyküsü $(\% 36,4)$, malignite $(\% 28,7)$ ve obezite $(\% 21,1)$ idi. Proflaksi almasi gereken 170 hasta vard1 ve bunların 56'sina (\%32,9) profilaksi uygulanıyordu. Klinikler ayrı ayrı incelendiğinde, risk gruplarına profilaksi uygulanma oranının en yüksek ortopedi $(\% 84,6)$ ve nöroloji $(\% 60,0)$ kliniklerinde bulunduğu, onları \%37,5 ile yoğun bakım ünitesinin izlediği görüldü. Kadın hastalıkları ve doğum, onkoloji, plastik cerrahi ile üroloji kliniğinde profilaksi uygulanan hasta saptanmadi.

\footnotetext{
Alındığı tarih: 30 Kasım 2011; Revizyon sonrası alınma: 29 Aralık 2011; Kabul tarihi: 18 Şubat 2012

Yazışma adresi (Address for correspondence): Nesrin Kıral, Şemsi Denizer Cad. E-5 Karayolu Cevizli Mevkii Kartal 34890 İstanbul; E-posta: drnesrinkiral@yahoo.com (C) 2012 Türkiye Solunum Araştırmaları Derneği (TÜSAD)

Solunum 2012;14(2):79-83 doi: 10.5505/solunum.2012.19981
}

Solunum Dergisi'ne www.solunum.org.tr adresinden ulaşabilirsiniz. 
risk patients for DVT would decrease the incidence of venous thromboembolism and the associated morbidity and mortality. We believe that the appropriate practice of prophylaxis could only be achieved through education.

Keywords: Hospitalized patients, pulmonary embolism, prophylaxis, thromboembolism
Sonuç: Hastanemizde venöz tromboemboli proflaksisine gereken önemin verilmediğini, risk grubundaki hastalara proflaksi uygulanması ile venöz tromboemboli insidansının ve ona bağlı morbidite ile mortalitenin azalacağını düşünüyoruz. Bunu da eğitimle başarabileceğimiz kanaatindeyiz.

Anahtar kelimeler: Tromboemboli, pulmoner emboli, profilaksi, yatan hasta

\section{INTRODUCTION}

Venous thromboembolic disorder is one of the most important health problems worldwide. Because of the delay and difficulty in diagnosis due to the insidious clinical presentation or misdiagnosis of venous thromboembolism (VTE) and high prevalence among hospitalized patients, prophylaxis of this disease have become a point of interest. Currently, it is the main etiological issue for preventable hospital deaths. It is evident that pulmonary thromboembolism (PTE) prevention relies mainly on prevention of formation of deep vein thrombosis. Therefore identification of high risk groups for VTE, duration of hospital stay for increased thromboembolism risk and effective therapeutic options with low risk profile for complications should be emphasized. Appropriate and effective prophylactic treatment cost less and is safer than the treatment of the disease itself, decreasing the incidence of morbidity and mortality. ${ }^{1}$

Placebo controlled studies showed that objectively proven VTE incidence changed between 5\% to $15 \%$ among acutely hospitalized patients and with appropriate VTE prophylaxis fatal pulmonary embolism frequency decreased by a half to three quarters among these patients. ${ }^{2}$ Although there are guidelines recommending the initiation of prophylactic treatment in patients hospitalized with VTE risk, the use of prophylaxis has been reported to be low and inappropriate. ${ }^{3,4,5}$

Present study was designed to assess the frequency of DVT prophylaxis among hospitalized patients carrying a high risk factor for VTE.

\section{MATERIALS AND METHODS}

Patients hospitalized for reasons other than pulmonary embolism were visited and their respective medical records were evaluated. Visits were completed in a day. A total of 275 patients in surgery, orthopedics, intensive care, internal medicine, oncology, plastic surgery, pulmonary diseases, neurology, neurosurgery and urology clinics were examined. Patient demographics, clinic and laboratory characteristics, duration of hospitalization, risk factors for DVT and PE were assessed. Requirement of prophylaxis was determined in accordance to 2001 ACCP criteria. ${ }^{6}$ The current status and contraindications of prophylactic treatment were also documented.

\section{RESULTS}

Two hundred and seventy five patients hospitalized with a reason other than pulmonary embolism were visited and their medical records were evaluated. Of the 275 patients, 134 $(48.7 \%)$ were females and $141(51.3 \%)$ males. The mean age was $53.09 \pm 19$ years. The mean length of hospital stay was $8.1 \pm 10.1$ days. Most common risk factors were found to be older age $(52.0 \%)$, immobility $(38.9 \%)$, history of surgical operation $(36.4 \%)$, malignancy $(28.7 \%)$ and obesity $(21.1 \%)$. The risk factors for VTE, total number of risk factors for each patient and rate of prophylactic treatment are presented in Table I, II. Among 275 patients, while 170 patients required prophylactic treatment according to the ACCP criteria; only $56(32.9 \%)$ were found to have received prophylactic treatment. For prophylactic treatment, low molecular weight

Table I. Distribution of risk factors among patients with VTE risk

\begin{tabular}{|l|c|c|}
\hline Risk factor & $\mathbf{n}$ & $\mathbf{( \% )}$ \\
\hline Older age & 143 & 52.0 \\
\hline Immobilization & 107 & 38.9 \\
\hline Operation & 100 & 36.4 \\
\hline Malignancy & 79 & 28.7 \\
\hline Obesity & 58 & 21.1 \\
\hline Congestive heart failure & 27 & 9.8 \\
\hline Fracture & 23 & 8.4 \\
\hline Stroke & 17 & 6.2 \\
\hline Central catheterization & 14 & 5.1 \\
\hline Trauma & 12 & 4.4 \\
\hline Postpartum period & 10 & 3.6 \\
\hline Respiratory failure & 7 & 2.5 \\
\hline History of VTE & 5 & 1.8 \\
\hline OCs-HRT ${ }^{*}$ use & 1 & 0.04 \\
\hline
\end{tabular}

*OC: oral contraceptive, HRT: Hormone replacement therapy 
Table II. Number of risk factors among patients with VTE risk and rate of prophylactic treatment

\begin{tabular}{|c|c|c|c|c|}
\hline Number of risk factors & VTE* $^{*}(n)$ & $\begin{array}{l}\text { Required to have } \\
\text { prophylaxis (n)** }\end{array}$ & $\begin{array}{c}\text { Having }{ }^{* * *} \\
\text { prophylaxis (n) }\end{array}$ & $\begin{array}{l}\text { Rate of prophylaxis } \\
(\%)\end{array}$ \\
\hline 1 risk factor & 77 & 21 & 3 & 14.3 \\
\hline 2 risk factors & 61 & 46 & 10 & 21.7 \\
\hline 3 risk factors & 62 & 57 & 20 & 35.1 \\
\hline 4 risk factors & 31 & 30 & 14 & 46.7 \\
\hline$\geq 5$ risk factors & 17 & 16 & 9 & 56.2 \\
\hline
\end{tabular}

heparin (LMWH) was administered as the method of prophylaxis in all except one patient. In one patient, LMWH was contraindicated and varicose socks were used. A separate analysis of distribution of patients with respect to clinical departments showed that patients in orthopedics $(84.6 \%)$ and neurology $(60.0 \%)$ clinics had the highest rate of prophylactic treatment followed by intensive care unit $(37.5 \%)$. No patient was found to have received prophylactic treatment in obstetrics and gynaecology, oncology, plastic surgery and urology departments. Rate of prophylactic treatment in patients having a risk for VTE is shown in Table III.

\section{DISCUSSION}

In the present study, we showed that venous thromboemboli prophylaxis was ignored in patients hospitalized with a risk factor for VTE.

Venous thromboembolic disorder is one of the most important health problems worldwide with a high prevalence among hospitalized patients. VTE incidence has been reported as $5-15 \%$ in acutely hospitalized patients. Currently, it is the main etiological concern for preventable hospital deaths. With appropriate prophylaxis fatal pulmonary

Table III. Distibution of the rate of prophylactic treatment in patients having a risk for VTE in respect to clinics

\begin{tabular}{|l|c|c|c|}
\hline Clinic & $\begin{array}{c}\text { Required to have } \\
\text { prophylaxis } \mathbf{( n )}\end{array}$ & $\begin{array}{c}\text { Patients having } \\
\text { prophylaxis (n) }\end{array}$ & Rate of prophylaxis (\%) \\
\hline General surgery & 38 & 11 & 28.9 \\
\hline Orthopedics & 26 & 22 & 84.6 \\
\hline Internal medicine & 21 & 5 & 23.8 \\
\hline Intensive care & 16 & 6 & 37.5 \\
\hline Neurology & 15 & 9 & 60.0 \\
\hline Neurosurgery & 12 & 1 & 8.3 \\
\hline Oncology & 11 & 0 & 0 \\
\hline Gynecology & 10 & 0 & 0 \\
\hline Plastic surgery & 6 & 0 & 0 \\
\hline Pulmonary diseases & 10 & 2 & 20 \\
\hline Urology & 5 & 0 & 0 \\
\hline Total & $\mathbf{1 7 0}$ & $\mathbf{5 6}$ & $\mathbf{3 2 . 9}$ \\
\hline
\end{tabular}


embolism frequency has been decreased by $50-75 \%$ among hospitalized patients. ${ }^{2}$ Appropriate and effective prophylactic treatment costs less and is safer than the treatment of the disease itself. ${ }^{1}$ Despite these facts, the use of prophylaxis was reported to be low and inappropriate in many studies. ${ }^{3,4,5}$

Pulmonary embolism is a frequent and preventable cause of death in hospitalized patients. As shown by autopsy studies, $10 \%$ of deaths during hospitalization was due to pulmonary embolism. ${ }^{2}$ Among the cases of pulmonary embolism 95\% originate from deep venous clots in lower extremities and are often asymptomatic. Screening methods are not helpful for high risk patients, therefore commencing routine prophylactic treatment for these individuals is suggested. ${ }^{7,8}$ Appropriate prophylactic treatment has been recommended in the guidelines of ACCP. 6,9

Studies performed at medical and surgical intensive care unit showed that $10 \%$ of patients had DVT on admittance to intensive care unit. ${ }^{7}$ In another study, DVT incidence was assessed to be $30 \% .{ }^{10}$ During the time of hospitalization in intensive care unit prolonged immobilization, central venous catheterization or other invasive interventions increase the DVT risk. Similarly, in patients with multisystem trauma, in particular orthopedics trauma, cranial or spinal trauma, incidence of DVT was reported as $50-65 \%{ }^{7,10}$ Khaldi et al reported that in the first week of a neurosurgical procedures frequency of DVTs was $84 \%$, increasing to $92 \%$ in the second week. They demostrated a lineer correlation between the duration of surgery and DVT development. ${ }^{11}$

In our hospital, $37.5 \%$ of the patients hospitalized in intensive care unit were receiving venous thromboembolism prophylaxis. In the study of Kizgin et al., $52.9 \%$ of the patients were found to be administered prophylactic treatment in intensive care unit. ${ }^{5}$ Keane et al. demonstrated that only $32.9 \%$ of patients received prophylactic treatment in internal intensive care unit. ${ }^{10}$

Research showed that, most of the patients hospitalized for symptomatic venous thromboembolism did not have a history of recent operation and that the incidence of fatal pulmonary embolism was higher among patients hospitalized with an acute medical illness compared to surgical patients.,12

There is enough evidence to suggest that VTE prophylaxis is necessary in patients with high medical risk. Nevertheless, previous studies report that only $1 / 3$ of high risk medical patients get VTE prophylaxis. ${ }^{13}$ In the study of Panju et al, $54 \%$ of the hospitalized medical patients recommended for prophylaxis received pharmacological VTE prophylaxis. ${ }^{14}$ Twenty eight percent of medical patients and $67 \%$ of surgery patients had prophylaxis in Monreal's study. ${ }^{15}$

Thromboembolic disease incidence was reported with varying rates among patients hospitalized in internal medicine units depending on the type of disease. While VTE risk was found to be $3 \%$ among patients without a risk factor, the risk increased to $50 \%$ in patients with a previous history of VTE . Massive pulmonary thromboembolism comprises the $4-8 \%$ of the etiology of deaths in internal medicine units. ${ }^{16}$ Twenty eight percent of internal medicine patients and 35\% of surgery patients were found to receive prophylaxis in our hospital.

ACCP guidelines ${ }^{6}$ recommend the use of low molecular weight heparin (LMWH) as the risk of thrombocytopenia is lower with LMWH as compared to free heparin. DVT incidence was reported to be decreased by $20 \%$ with unfractionated heparin and 30\% with low molecular weight heparin as compared to placebo. ${ }^{7}$ The most common pharmacological method used in prophylaxis in our hospital was LMWH $(98.2 \%)$.

In the present study, rate of prophylaxis in high risk hospitalized patients was found to be low $(32.9 \%)$. In literature, limited use of VTE prophylaxis when it is necessary was shown to be dependent to other factors. Most common causes reported were unawareness of disease and lack of information about the guidelines. ${ }^{2,17}$ Complexity of the current guidelines may have an additional role in limited use of prophylaxis. Bergmann et al reported that there is a necessity to improve available guidelines for evaluating VTE risk and providing prophylaxis to hospitalized medical patients. ${ }^{18}$ Recent ACCP guidelines for prevention of $\mathrm{VTE}^{19}$ supports the educational steps that may increase the comprehensibility and awareness of the treatment guidelines. Additionally, lack of official protocols in many hospitals for the prevention of VTE in patients under VTE risk have been reported. ACCP recommends the establishment of these protocols and use of computerized reminder systems. With this approach use of prophylaxis may be increased and subsequently a decrease in the DVT and PTE rates in hospitalized patients would be seen. ${ }^{2}$ When results of the ENDORSE (Epidemiologic International Day for the Evaluation of Patients at Risk for Venous Thromboembolism in the Acute Hospital Care Setting) 2006 and 2009 were compared, a significant, $43.9 \%(\mathrm{p}=0.002)$ increase was found in medical patients, which proves the success of lectures presenting the facts and focusing on the increase in medical prophylaxis during the time period between the two studies. ${ }^{20}$

In conclusion, PTE remains a serious clinical problem. Awareness of risk factors for VTE and commencement of routine prophylaxis in these individuals are important approaches. There is a need for establishment of guidelines to be used by physicians for VTE prophylaxis. We believe that, increasing the awareness of physicians about the importance of VTE prophylaxis in hospitalized patients by education may help to overcome this problem.

\section{REFERENCES}

1. Öngen G. Proflaktik Tedavi. In: Metintaş M, ed. Pulmoner tromboemboli. Eskişehir: ASD Toraks Yayınları, 2001;193-211. 
2. Tapson VF, Decousus H, Pini M, Chong BH, Froehlich JB, Monreal $\mathrm{M}$, et al. Venous thromboembolism prophylaxis in acutely ill hospitalized medical patients-findings from the international medical prevention registry on venous thromboembolism. Chest 2007;132:936-945.

3. Ageno W, Squizzato A, Ambrosini F, Dentali F, Marchesi C, Mera V, et al. Thrombosis prophylaxis in medical patients: a retrospective review of clinical practice patterns. Haematologica 2002;87:746-750.

4. Ahmad HA, Geissler A, MacLellan DG. Deep venous thrombosis prophylaxis: are guidelines being followed? ANZ J Surg 2002;72:331-334.

5. Kızkın Ö, Hacıevliyagil S.S, Günen H. Yatan Hastalarda Tromboemboli Profilaksinin Klinik Önemi. İnönü Üniversitesi Tip Fakültesi Dergisi 2004;11:155-159.

6. Geerts WH, Heit JA, Clagett GP, Pineo GF, Colwell CW, Anderson FA Jr, et al. Prevention of venous thromboembolism. Chest 2001;119(1 suppl):132S-175S.

7. Attia J, Ray JG, Cook DJ, Douketis J, Ginsberg JS, Geerts WH. Deep vein thrombosis and its prevention in critically ill adults. Arch Intern Med 2001;161:1268-1279.

8. Hyers TM. Venous thromboembolism. Am J Respir Crit Care Med 1999;159:1-14.

9. Geerts WH, Pineo GF, Heit JA, Bergqvist D, Lassen MR, Colwell $\mathrm{CW}$, et al. Prevention of venous thromboembolism the seventh ACCP conference on antithrombotic and thrombolytic therapy. Chest 2004;126:338S-400S.

10. Keane MG, Ingenito EP, Goldhaber SZ. Utilization of venous thromboembolism prophylaxis in the medical intensive care unit. Chest 1994;106:13-14.

11. Khaldi A, Helo N, Schneck MJ, Origitano TC. Venous thromboembolism: deep venous thrombosis and pulmonary embolism in a neurosurgical population. J Neurosurg 2011;114:40-46. Epub 2010 Sep 3.

12. Baglin TP, White $\mathrm{K}$, Charles A. Fatal pulmonary embolism in hospitalised medical patients. J Clin Pathol 1997;50:609-610.

13. Rahim SA, Panju A, Pai M, Ginsberg J. Venous thromboembolism prophylaxis in medical inpatients: a retrospective chart review. Thromb Res 2003;111:215-219.

14. Panju M, Raso D, Patel A, Panju A, Ginsberg J. Evaluation of the use of venous thromboembolism prophylaxis in hospitalised medical patients. J R Coll Physicians Edinb 2011;41:304-308.

15 Monreal M, Kakkar AK, Caprini JA, Barba R, Uresandi F, Valle R, et al. The outcome after treatment of venous thromboembolism is different in surgical and acutely ill medical patients. Findings from the RIETE registry. J Thromb Haemost 2004;2:1892-1898.

16. Kolsuz Mustafa. Venöz trombüs ve tromboemboli risk faktörleri. In: Metintaş M, ed. Pulmoner tromboemboli. Eskişehir: ASD Toraks Yayınlar1, 2001;21-41.

17. Arnold DM, Kahn SR, Shrier I. Missed opportunities for prevention of venous thromboembolism: an evaluation of the use of thromboprophylaxis guidelines. Chest 2001;120:1964-1971.

18. Bergmann JF, Cohen AT, Tapson VF, Goldhaber SZ, Kakkar AK, Deslandes B, et al. Venous thromboembolism risk and prophylaxis in hospitalised medically ill patients. The ENDORSE Global Survey. Thromb Haemost 2010;103:736-748. Epub 2010 Feb 2.

19. Schünemann HJ, Cook D, Grimshaw J, Liberati A, Heffner J, Tapson $\mathrm{V}$, et al. Antithrombotic and thrombolytic therapy: from evidence to application: the Seventh ACCP Conference on Antithrombotic and Thrombolytic Therapy. Chest 2004;126:688S-696S.

20. Losonczy H, Tar A. Results of ENDORSE-2-HUNGARIA study. Repeated assessment of the prevalence of venous thromboembolism risk and prophylaxis in acute hospital care setting. Orv Hetil 2010;151:843-852. 